\title{
Sexual reproduction in the Caribbean coral genus Isophyllia (Scleractinia: Mussidae)
}

\author{
Derek Soto $^{\text {Corresp., }}{ }^{1}$, Ernesto Weil ${ }^{1}$ \\ ${ }^{1}$ Department of Marine Science, Universidad de Puerto Rico, Recinto de Mayagüez, Mayagüez, Puerto Rico, United States \\ Corresponding Author: Derek Soto \\ Email address: derek.soto@upr.edu
}

The sexual pattern, reproductive mode, and timing of reproduction of Isophyllia sinuosa and Isophyllia rigida, two Caribbean Mussids, were assessed by histological analysis of specimens collected monthly during 2000-2001. Both species are simultaneous hermaphroditic brooders characterized by a single annual gametogenetic cycle. Spermatocytes and oocytes of different stages were found to develop within the same mesentery indicating sequential maturation for extended planulation. Oogenesis took place during May through April in I. sinuosa and from August through June in I. rigida. Oocytes began development 7-8 months prior to spermaries but both sexes matured simultaneously. Zooxanthellate planulae were observed in I. sinuosa during April and in I. rigida from June through September. Higher polyp and mesenterial fecundity were found in I. rigida compared to $I$. sinuosa. Larger oocyte sizes were found in $I$. sinuosa than in $I$. rigida, however larger planula sizes were found in I. rigida. Hermaphroditism is the exclusive sexual pattern within the Mussidae while brooding has been documented within the related genera Mussa, Scolymia and Mycetophyllia. This study represents the first description of the sexual characteristics of $I$. rigida and provides an updated description of I. sinuosa. 
Sexual Reproduction in the Caribbean Coral Genus Isophyllia

(Scleractinia: Mussidae)

Derek Soto • Ernesto Weil

Department of Marine Sciences, University of Puerto Rico

Call Box 9000, Mayaguez PR 00681

derek.soto@upr.edu

\section{ABSTRACT}

8 The sexual pattern, reproductive mode, and timing of reproduction of Isophyllia sinuosa and

9 Isophyllia rigida, two Caribbean Mussids, were assessed by histological analysis of specimens

10 collected monthly during 2000-2001. Both species are simultaneous hermaphroditic brooders

11 characterized by a single annual gametogenetic cycle. Spermatocytes and oocytes of different

12 stages were found to develop within the same mesentery indicating sequential maturation for

13 extended planulation. Oogenesis took place during May through April in I. sinuosa and from

14 August through June in I. rigida. Oocytes began development 7-8 months prior to spermaries but

15 both sexes matured simultaneously. Zooxanthellate planulae were observed in $I$. sinuosa during

16 April and in I. rigida from June through September. Higher polyp and mesenterial fecundity were

17 found in I. rigida compared to $I$. sinuosa. Larger oocyte sizes were found in $I$. sinuosa than in $I$.

18 rigida, however larger planula sizes were found in I. rigida. Hermaphroditism is the exclusive

19 sexual pattern within the Mussidae while brooding has been documented within the related

20 genera Mussa, Scolymia and Mycetophyllia. This study represents the first description of the

21 sexual characteristics of I. rigida and provides an updated description of I. sinuosa.

\section{Introduction}

Reproduction in corals consists of a sequence of events which include: gametogenesis,

24 spawning (broadcasters), fertilization, embryogenesis, planulation (brooders), dispersal, 
25 settlement and recruitment (Harrison and Wallace 1990). The success of the reproductive effort is

26 determined largely by the timing, duration, frequency and intensity of the aforementioned events

27 (Babcock et al. 1986). In corals, sexual pattern, mode of reproduction, fertilization, larval

28 dispersal, recruitment and survivorship are key components in determining evolutionary fitness

29 (Szmant 1986; Edmunds 2005; Vermeij 2006; Weil et al. 2009b; Pinzon and Weil 2011) which is

30 defined as the product of sexual output (fecundity) and survivorship (Metz et al. 1992).

31 Consequently, the ability of coral species to adapt to modern-day environmental pressures

32 depends greatly on the ability of species to reproduce effectively.

33 The reproductive characteristics of some scleractinian groups have been more thoroughly

34 studied than others, however, little is known about the reproductive patterns of many Caribbean

35 coral species and some of the available information is conflictive or incomplete (Fadlallah 1983;

36 Harrison, 1990; 2011; Weil and Vargas 2010; Pinzon and Weil, 2011). Of the approximately 60

37 Caribbean zooxanthellate coral species reported, thorough descriptions of their reproductive

38 characteristics and cycles are available for 19 species; many other studies available provide

39 partial or conflicting results (Weil 2003; Weil and Vargas 2010; Harrison 2011). Reproductive

40 studies of the sexual patterns of I. sinuosa were among the first studies of such nature performed

41 in the Caribbean (Duerden 1902). These were limited to histological observations of oocytes in a

42 few colonies of I. sinuosa (Fig. 1A, B), therefore, the species is classified as gonochoric. This

43 characterization contrasts with the reproductive mode of other studied Mussids which are

44 classified as hermaphroditic. Currently, there is no information available on the reproductive

45 biology of I. rigida (Fig. 1C, D).

46 This study characterizes the reproductive biology of $I$. rigida and $I$. sinuosa in terms of

47 sexual pattern, mode of development, gametogenic cycles, and fecundity. These fundamental

48 aspects of the physiology of this taxa are understudied. Knowledge of the reproductive biology

49 and ecology of coral species is important for the interpretation of their population and ecological 
50 dynamics, their patterns/potential for dispersal, and their local and geographical distribution. The

51 threats currently faced by coral reefs and the ongoing global effort to understand why corals are

52 dying highlight the need to expand our understanding of basic coral physiology.

\section{Materials and Methods}

54 Sampling for this study was carried out at La Parguera Natural Reserve, off the southwest

55 coast of Puerto Rico (Fig. 2). This complex reef environment is among the many regions

56 experiencing deterioration by anthropogenic and environmental climate influences at local and

57 global scales. Coral reefs in La Parguera are important local economic drivers, supporting

58 artisanal and recreational fishing, tourism, recreational activities and also protect coastal

59 settlements, seagrass communities and other wetland habitats from the effects of hurricanes and

60 coastal erosion (Ballantine et al. 2008).

61 At least five unique sample cores were collected monthly for 14 months between March

622000 and May 2001 (Fig. 3A). A total of 89 samples of each species were collected. Colonies

63 were selected by searching in a zig-zag pattern over the distributional range of both species (5-

64 18m). Samples were collected from San Cristobal reef (1755'24.88"N 67 6'14.52"W),

65 Caracoles reef $\left(17^{\circ} 57^{\prime} 46.02 " \mathrm{~N}, 67^{\circ} 2^{\prime} 8.21^{\prime \prime} \mathrm{W}\right)$, Media Luna reef $\left(1^{\circ} 56^{\prime} 22.68^{\prime \prime} \mathrm{N}, 67^{\circ}\right.$

66 2'43.26"W), Pinaculos (1756'1.13"N, 67 0'39.75"W), Turrumote reef $\left(17^{\circ} 56^{\prime} 13.56^{\prime \prime} \mathrm{N}, 67^{\circ}\right.$

67 1'8.92"W), Beril (1752'47.85"N, 6659'1.40"W), El Palo (1755’50.2”N, 6705'36.9”W), Laurel

68 (1755'50.2"N, 6705'36.9"W) and Enrique (1755'50.2"N, 6705’36.9"W) (Fig. 3B, Fig. 4).

69 Sample cores were placed in Zenker Formalin (Helly's solution) for 24 hours, rinsed and

70 then decalcified in $10 \% \mathrm{HCl}$ solution. Tissues were then cleaned and placed in plastic tissue

71 holders. Preserved samples were sequentially dehydrated in the rotary tissue processor under $70 \%$

72 and 95\%, ethanol, Tissue Dry, and xylene solution (Tissue Clear III). Samples were embedded 
73 into Paraplast blocks then sectioned using a rotary microtome. 8-10 strip sections (7-10 $\mu \mathrm{m})$ were

74 obtained from each embedded block and placed onto glass slides. Finished tissue slides were 75 stained utilizing a modified Heidenhain’s Aniline-Blue method (Coolidge and Howard, 1979) to 76 examine the maturation stages of gametocytes and embryos.

77 Slides were examined under an Olympus BX40 compound microscope coupled to an

78 Olympus DP26 digital microscope camera. Images were captured utilizing Olympus cellSens 1.7

79 imaging software. The sexual pattern, gametogenic cycle and fecundity of each species were

80 determined by observing the gametocyte development throughout the collection year. Gamete

81 stages were characterized according to Szmant-Froelich et al. (1985). Oocyte sizes were obtained

82 using cellSens, by taking perpendicular measurements at the cell's widest points. Cell length and

83 width measurements were used to calculate geometric area. Fecundity was assessed by counting

84 oocytes per mesentery (I. sinuosa $\mathrm{n}=120$; I. rigida $\mathrm{n}=60$ ) and per polyp (I. sinuosa $\mathrm{n}=10$; I. rigida

$85 \mathrm{n}=5$ ) on histologic cross-sections during months with the highest proportion of mature oocytes ( $I$.

86 sinuosa April 2001 n=5; I. rigida May 2001 n=5).

87 In April 2012, several presumed gravid colonies of each species were collected and placed

88 in an open seawater aquarium system to observe planulation. Two colonies of each species were

89 placed within 6 gallon aerated aquariums under continuously circulating seawater and daylight

90 synchronized lights. Specimens were placed under mesh-lined PVC pipes allowing water to

91 freely circulate. Traps were checked daily for larvae over a 90-day period.

\section{Statistical Analyses}

93 Results are expressed as means \pm standard error. All statistical tests were performed using

94 the RStudio 0.99.484 software platform (R Studio Team, 2015) using the stats package (R Core

95 Team, 2015). Normality was assessed using the Shapiro-Wilk test performed with the R function

96 shapiro.test. Equality of variance was tested using the $\mathrm{F}$ test performed with the R function 
97 var.test. Differences in fecundity were tested by means of a Wilcoxon rank sum test with

98 continuity correction performed with the R function wilcoxon.test.

99 Collection Permit

100 All coral tissue samples were collected under a General Collection Permit granted by the

101 Puerto Rico Department of Natural Resources (DNER) to the Faculty of the Department of 102 Marine Sciences UPRM.

\section{Results}

104 I. sinuosa

105 Stage I oocytes are small $\left(78.92 \pm 13.15 \mu \mathrm{m}^{2}\right)$, stain pink and are characterized by sparse 106 cytoplasm and prominent nuclei (Fig. 4A). Oocytes originate within the linings of the mesoglea 107 in the central regions of the mesenteries. Stage II oocytes are larger than stage I cells 108 (144.54 $\pm 43.19 \mu \mathrm{m}^{2}$ ), exhibit prominent nuclei and abundant cytoplasm (Fig. 4A). Stage III 109 oocytes are larger than stage II $\left(264.51 \pm 37.24 \mu \mathrm{m}^{2}\right)$, tend to have a round shape, stain pink or 110 red, and are characterized by many cytoplasmic globules which produce a grainy appearance 111 (Fig. 4B). Stage IV oocytes are larger and boxier than stage III (376.69 $\left.\pm 73.20 \mu \mathrm{m}^{2}\right)$. This stage is 112 characterized by dark staining nuclei and large globules in the cytoplasm (Figs. 4C, D \& E).

113 No stage I spermaries were found, suggesting this stage occurs briefly and/or is difficult 114 to differentiate using the current method. Stage II spermaries form small poorly defined bundles 115 which form in the mesenteries surrounding oocytes (Fig. 4C). Stage III spermaries form small 116 sacs with well-defined borders (Fig. 4D) and contain bright red staining spermatids. Stage IV 117 spermaries stain dark red and are larger than stage III. Tails visible on spermatozoa at high 118 magnification are indicative of stage V spermaries (Fig. 4E). Spermary sizes were not measured. 
120 stain pink. During this stage, zooxanthellae become visible within the planulae. Stage II planulae

$121\left(455.45 \pm 32.84 \mu \mathrm{m}^{2}\right)$ are characterized by an outer layer composed of columnar cells which 122 contain nematocysts and cilia (Fig. 4F). Developing mesenteries can be seen within the 123 gastrodermis of stage III planula $\left(501.98 \pm 44.68 \mu \mathrm{m}^{2}\right)$. Stage IV planula were not observed.

The gametogenic cycle of $I$. sinuosa is summarized in Fig. 5. Weekly sea surface 125 temperature measurements taken during the collecting period are included for reference (Fig. 126 5A). Oogenesis in $I$. sinuosa lasts approximately 11 months (Fig. 5B). Onset of oogenesis was 127 determined to occur during May 2000 and during April 2001. Onset of oogenesis was determined 128 as the month of appearance of stage I and II oocytes after the culmination of the previous 129 gametogenic cycle. Stage II oocytes were prevalent in tissues during all months sampled except 130 during November 2000 and January 2001. Stage III oocytes were observed in all sampled months 131 except April 2001. Stage IV oocytes were observed between August 2000 through May 2001. Spermatogenesis takes places during 4 months (Fig. 5C). Onset of spermatogenesis was

133 not determined because stage I spermaries were not identified. Stage II spermaries were observed 134 during January through February 2001. Stage III spermaries were visible from January through

135 March 2001. Stage IV spermaries were present in March 2001. Stage V spermaries were present 136 in tissues in April 2001.

137 Stage I-III planulae were observed in histologic sections during April 2001 (Fig. 5D). The 138 identification of planulae on tissue sections coincided with a sharp decrease in the proportion of 139 colonies containing mature (IV) oocytes. No larvae were collected from specimens placed in 140 aquaria for observation.

141 I. rigida 
143 cytoplasm and a large nucleus. Stage II oocytes are larger than stage I cells $\left(101.25 \pm 23.09 \mu \mathrm{m}^{2}\right)$,

144 are ovoid shaped and feature a prominent nucleus and nucleolus (Fig. 6A). A pink-staining

145 nucleus and red nucleolus can clearly be identified in many stage III oocytes $\left(148.77 \pm 49.35 \mu \mathrm{m}^{2}\right)$

146 (Fig. 6B). Stage IV oocytes are large (190.40 $\left.\pm 45.18 \mu \mathrm{m}^{2}\right)$, irregularly shaped and contain large

147 vacuoles in the ooplasma which give it a grainy appearance (Figs. 6C \& D).

148 Stage I spermaries were not detected in I. rigida. Stage II spermaries were observed 149 forming adjacent to stage III eggs (Fig. 6B). Spermaries typically adopt a spherical shape and 150 often form in series resembling a string of beads (Figs. 6B \& C). Stage III spermaries form small 151 oblong sacs and stain red (Fig. 6C). Stage IV spermaries are densely packed with sperm, have 152 irregular shapes, stain dark red to brown. Stage V spermaries stain darker than stage IV (Fig. 6E)

153 but are characterized by tails on spermatozoa under high magnification. No measurements were 154 collected for spermaries.

155 Stage I planulae are approximately the same size as stage IV oocytes (approximately $156324.01 \pm 71.64 \mu \mathrm{m}^{2}$ ), stain pink, and contain zooxanthellae in the epidermis. Zooxanthellae were 157 observed within planula beginning at this stage. Stage II planulae are larger $\left(521.27 \pm 84.18 \mu \mathrm{m}^{2}\right)$ 158 (Fig. 6F) and exhibit an epidermis consisting of columnar epithelium similar to I. sinuosa. Stage

159 III and stage IV larvae measure $818.91 \pm 82.96 \mu \mathrm{m}^{2}$ and $951.78 \pm 176.36 \mu \mathrm{m}^{2}$ respectively, and 160 show clear development of the mesenteries.

161 The gametogenic cycle of I. rigida is summarized in Fig. 7. Weekly sea surface 162 temperature measurements taken during the collecting period are included for reference (Fig 7A).

163 Oogenesis in I. rigida lasts approximately 10 months (Fig. 7B). Oogenesis began during August

164 2000. Stage II oocytes were observed in tissues in March 2000 and August 2000 to April 2000.

165 Stage III oocytes were observed in March 2000, May and June 2000 and from January 2001 
166 through May 2001. Stage IV oocytes were observed in samples collected during March, May and

167 June 2000, and February, April and May 2001.

168 Spermatogenesis in I. rigida is estimated to last approximately 2-3 months (Fig. 7C).

169 Onset of spermatogenesis was not determined because stage I spermaries were not identified.

170 Stage II spermaries were observed in May 2000. Stage III spermaries were visible in May 2000.

171 Stage IV spermaries were observed first in June 2000. Stage V spermaries were observed in May 1722000.

173 Stage I planulae were observed in June 2000 indicating the onset of embryogenesis (Fig.

174 7D). The appearance of planulae coincided with a sharp decrease in the proportion of colonies 175 containing mature oocytes. Stage II planulae were observed during June 2000 and May 2001.

176 Stage III planulae were observed from June through August 2000. Stage IV planulae were 177 observed in tissues from June throughout September 2000. No larvae were collected from 178 specimens placed in aquaria for observation.

\section{Fecundity}

180

Mesenterial fecundity in I. sinuosa (11.13 \pm 8.27 oocytes/mesentery) was significantly

181 higher (Wilcoxon-rank sum test, $\left.W=1208.5, p<2.2 \times 10^{-16}\right)$ than in $I$. rigida $(1.70 \pm 3.52$

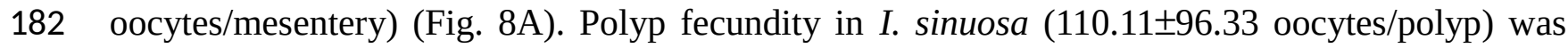
183 significantly higher (Wilcoxon-rank sum test, $W=18, p=0.018$ ) compared to $I$. rigida 184 (20.45 \pm 23.91 oocytes/polyp) (Fig. 8B).

\section{Oocyte Size}

Measurements of oocyte geometric area in I. sinuosa (range 43.94-463.79 $\mu \mathrm{m}^{2}$ ) show an

187 increase in the size of oocytes as maturity progresses from April through March (Fig. 9A). Mean 188 geometric area is lowest during the month of June $2000\left(97.22 \pm 28.85 \mu \mathrm{m}^{2}\right)$ and greatest during 189 February $2001\left(333.95 \pm 74.32 \mu \mathrm{m}^{2}\right)$. The appearance of planulae in histological sections during 
190 the month of April $2001\left(459.07 \pm 45.83 \mu \mathrm{m}^{2}\right.$ ) (range: $404.07-548.49 \mu \mathrm{m}^{2}$ ) coincides with a sharp

191 decrease in mean geometric area of oocytes compared to the previous month (285.68 $\pm 96.46 \mu \mathrm{m}^{2}$

192 vs. $143.28 \pm 84.07 \mu \mathrm{m}^{2}$ ). Measurements of oocyte geometric area in I. rigida (range 43.31-307.35

$193 \mu \mathrm{m}^{2}$ ) also show a trend of increasing oocyte size as maturity progresses from August through

194 June (Fig. 9B). Mean geometric area is lowest during the month of September 2000 (68.35 \pm 17.04

$\left.195 \mu \mathrm{m}^{2}\right)$ and greatest during June $2000\left(210.54 \pm 42.90 \mu \mathrm{m}^{2}\right)$. Mean planulae area was greatest during

196 the month of July $2000\left(909.48 \pm 250.56 \mu \mathrm{m}^{2}\right)$ and ranged from $241.66-1183.96 \mu \mathrm{m}^{2}$. Mean oocyte

197 geometric area was greater in I. sinuosa than in I. rigida (Wilcoxon-rank sum test, $W=43911$,

$198 p<2.13 \times 10^{-13}$ ), however mean planulae geometric area was significantly higher in I. rigida

199 compared to $I$. sinuosa (Wilcoxon-rank sum test, $W=186, p=0.008$ ).

\section{Discussion}

201 Microscopic observations indicate that both $I$. sinuosa and I. rigida are simultaneous

202 hermaphrodites (gametes of both sexes are present in a single individual at the same time).

203 Gametes of both sexes are produced adjacent within the same mesentery (dygonism) in both

204 species. Both species are brooders (bear live young) which transfer endosymbiotic zooxanthellae

205 directly from parent to offspring. Both species are characterized by a single annual gametogenic

206 cycle. This study represents the first description of the sexual characteristics of I. rigida and

207 contradicts observations by Duerden (1902) which label I. sinuosa as a gonochoric species. The

208 incorrect classification of $I$. sinuosa as the sole gonochoric outlier within the traditional Mussidae

209 was a contrasting element in a group which is otherwise uniformly hermaphroditic (Duerden

210 1902; Fadlallah 1983; Richmond and Hunter 1990). This study confirms the dominant pattern of

211 sexual reproduction described for Mussid corals (Baird 2009) and provides further support for

212 conserved reproductive patterns within coral families (Harrison 2011). 
214 systematic affinities using molecular methods in combination with morphometric analyses. The

215 traditional Mussidae family has recently undergone extensive restructuring by separating Indo-

216 Pacific Mussids from their Atlantic counterparts which are more closely related to some members

217 of the family Faviidae (Fukami et al. 2004; 2008; Budd et al. 2012). The resulting 'modern'

218 Mussidae (clade XXI) is composed of the genera Mussa, Isophyllia, Mycetophyllia, and Scolymia

219 (Atlantic) under the Mussinae subfamily and Favia (Atlantic), Colpophyllia, Diploria, 220 Pseudodiploria, Manicina and Mussismilia under the Faviinae subfamily. Under the new 221 classification, hermaphroditism has been exclusively documented within all genera of the 222 subfamily Mussinae: Mycetophillia (Szmant-Froelich 1985; Morales 2006), Scolymia (Pires et al. 223 2000; Weil unpublished data) and Mussa (Steiner 1993) and within the subfamily Faviinae: Favia 224 (Soong 1991), Colpophyllia (Weil unpublished data), Diploria (Weil and Vargas 2009) 225 Pseudodiploria (Weil and Vargas 2009), Manicina (Johnson 1992), Mussismilia (Pires et al. 226 1999) (Table 1). Mode of development within the modern Mussidae is mixed; both brooding and 227 spawning species are present. Brooding has been documented within Mycetophyllia (Morales 228 2006), Scolymia (Pires et al. 2000; Weil unpublished data), and Manicina (Johnson 1992).

229 Broadcast spawning occurs in Colpophyllia (Weil unpublished data), Diploria (Weil and Vargas 230 2009), Pseudodiploria (Weil and Vargas 2009), and Favia (Soong 1991). Sexual mode exhibits 231 more plasticity than sexuality (Van Moorsel 1983; Harrison 1985): contrasting modes of 232 development exist within families and even within genera (Harrison 2011). Szmant (1986) suggested that sexual mode is potentially a function of habitat stability,

234 where successful recruiters would be small, rapidly maturing species, which produce many 235 offspring over short periods but subject to high mortality rates. Thus, the sexual modality of 236 species occupying unstable habitats would gravitate towards brooding because it increases the 237 chances of successful recruitment by reducing gamete and larval mortality even in low 
238 population densities. Edinger and Risk (1995) on noting a correlation between brooding and

239 eurytopy, hypothesized that brooding corals may preferentially survive in unstable habitats due to

240 higher recruitment success. The benefits provided by the brooding modality may partially explain

241 why, in recent decades, brooding corals have begun to dominate some Caribbean reefs following

242 degradation by natural and anthropogenic disturbances (Hughes 1994; Mumby 1999; Knowlton

243 2001; Irizarry and Weil 2009).

244 The close proximity of oocytes and spermaries within the same mesentery (dygonism) in

245 I. sinuosa and I. rigida suggests that it is possible that self-fertilization can occur in these species.

246 Generally, self-fertilization is not a favored method of fertilization in corals due to possibility of

247 inbreeding depression (Knowlton et al. 1993). Selfing, however, is thought to be advantageous in

248 sessile hermaphrodites which are ecologically distant from other mates and may have limited

249 access to gametes of the other sex, providing a viable alternative for successful fertilization (Ayre

250 \& Miller 2004; Darling et al. 2012; Sawada et al. 2014). These corals may then switch to sexually

251 produced larvae as population sizes increase (Ayre \& Reesing 1986). Selfing has been

252 documented in the brooding corals Seriatopora hystrix (Sherman 2008), Favia fragum and

253 Porites astreoides (Brazeau et al. 1998).

254 The duration of the gametogenic cycle is similar in I. sinuosa and I. rigida (11 and 10

255 months, respectively). Long oocyte generation times, differential gamete maturation, and long

256 brood retention times in Isophyllia suggest the possibility of multiple brooding events during a

257 single gametogenetic cycle. This strategy may increase reproductive output due to space

258 limitations within polyps. A single annual gametogenetic cycle is the dominant pattern in most

259 broadcasting corals such as Orbicella, Montastraea, Diploria, Porites, Acropora, Siderastrea

260 (Szmant 1986; Vargas 2002; Weil and Vargas 2009) and brooding Caribbean corals like Porites

261 and Mycetophyllia (Szmant 1986; Soong 1993; Vermeij et al. 2004; Morales 2006). Multiple 
262 spawning events have been documented in Acanthastrea lordhowensis (Wilson and Harrison

263 1997) and cannot be ruled out in these species.

264 Both species differ in the timing of oogenesis and planulogenesis events by various

265 months which suggests that opportunities for hybridization between both species are limited. The

266 dates of onset of oogenesis in both species (May in I. sinuosa and August in I. rigida) coincide

267 with warm local sea surface temperatures suggesting seasonal synchronization of the

268 gametogenic cycle. In I. sinuosa, planulae were observed in histologic sections during April 2001

269 which suggests that fertilization occurred during early April (most recent Full Moon: April 9). In

270 I. rigida, planulae were observed in June 2000 which suggests a fertilization date in late May

271 (most recent Full Moon: May 6, 2001). Various environmental factors have been shown to

272 correlate with coral reproductive cycles and may play a role in their synchronization, including

273 sea temperature, salinity, day length, light/dark cycles and tidal cycles (Harrison and Wallace

274 1990). Van Woesik et al. (2006) showed experimentally that some coral spawning schedules

275 correlate strongly with solar insolation levels prior to gamete release, however, water

276 temperatures are highly influential in determining actual gamete maturity. Van Woesik (2009)

277 also demonstrated a positive correlation between the duration of regional wind calm periods and

278 the coupling of mass coral spawnings. Studies with the brooding coral Pocillopora damicornis

279 revealed that synchronization of larval production was lost under constant artificial new moon

280 and full moon conditions, demonstrating that planulation in some species is linked to nighttime

281 irradiance (Jokiel et al. 1985).

282 Acquisition of the endosymbiont Symbiodinium in Isophyllia occurs directly from parent 283 to offspring (vertical transmission), a characteristic strongly linked to the brooding modality

284 (Baird 2009). Vertical symbiont transmission may be advantageous by providing larvae with

285 various Symbiodinium genotypes which may improve their ability to recruit successfully and 286 grow in different environmental conditions (Padilla-Gamiño et al. 2102). Brooded larvae are 
287 capable of motility immediately or shortly after planulation (Fadlallah 1983), in contrast to

288 broadcast spawned propagules which are positively buoyant and may take between 12-72 hours

289 to become motile (Baird et al. 2009). By avoiding the surface, brooded larvae may better avoid

290 exposure to high levels of solar radiation which may overwhelm the photosynthetic capacities of

291 zooxanthellae producing oxygen radicals (Tchernov et al. 2004) and cause tissue damage and

292 mortality (Lesser et al. 1990). However, under high temperature conditions, larvae of corals with

293 vertical symbiont transmission may suffer higher oxidative stress and tissue damage, suggesting

294 that these corals may be more vulnerable to the effects of ocean warming (Yakovleva et al. 2009).

295 There is increasing evidence that sexual reproduction in corals is highly susceptible to

296 natural and anthropogenic stressors that reduce fecundity, fertilization success, and larval survival

297 (Harrison and Wallace 1990; Harrison 2011). Increases in sea surface temperatures as a

298 consequence of global warming have produced widespread coral bleaching events and disease

299 outbreaks with massive mortality of susceptible individuals. This worldwide decline of coral

300 reefs underscores the need for understanding sexual reproduction in corals as the only mechanism

301 capable of safeguarding their future. Sexual recombination is an important prerequisite for the

302 selection of individuals which are to be able to adapt to the pressures of a changing environment.

303 A greater understanding of the mechanisms and variables in sexual reproduction in corals, in

304 combination with knowledge of the taxonomy and variability of the species, is essential for any

305 coral reef management strategy (Harrison and Wallace, 1990).

\section{Acknowledgements}

307 We would like to acknowledge I. Urreiztieta for her training and assistance with coral

308 histology. The authors would like to acknowledge the Department of Marine Sciences, University

309 of Puerto Rico Mayaguez (UPRM) for providing support for boat use, diving, and laboratory

310 space. We also thank the reviewers for their helpful comments which greatly enhanced this

311 manuscript. 


\section{References}

313

314

315

316

317

318

319

320

321

322

323

324

325

326

327

328

329

330

331

332

333

334

335

336

337

338

339

340

341

342

343

344

345

346

347

348

349

350

351

352

353

354

355

356

Ayre, D.J. \& Miller, K.J. (2004). Where do clonal coral larvae go? Adult genotypic diversity conflicts with reproductive effort in the brooding coral, Pocillopora damicornis. Marine Ecology Progress Series, 277, 95-105.

Ayre, D. \& Resing, J. (1986). Sexual and asexual production of planulae larvae in reef corals. Marine Biology, 90, 187-190.

Babcock, R. C., Bull, G. D., Harrison, P. L., Heyward, A. J., Oliver, J. K., Wallace, C. C., \& Willis, B. L. (1986). Synchronous spawnings of 105 scleractinian coral species on the Great Barrier Reef. Marine Biology, 90(3), 379-394.

Baird, A. H., Guest, J. R., \& Willis, B. L. (2009). Systematic and biogeographical patterns in the reproductive biology of scleractinian corals. Annual Review of Ecology, Evolution, and Systematics, 40, 551-571.

Ballantine, D. L., Appeldoorn, R. S., Yoshioka, P., Weil, E., Armstrong, R., Garcia, J. R., Otero, E., Pagan, F., Sherman, C., Hernandez-Delgado, E.A., \& Bruckner, A. (2008). Biology and ecology of Puerto Rican coral reefs. In Coral Reefs of the USA, 375-406. Springer Netherlands.

Boland, G. S. (1998). Spawning observations of the scleractinian coral Colpophyllia natans in the northwest Gulf of Mexico. Gulf of Mexico Science,16, 226-227.

Brazeau, D. A., Gleason, D. F., \& Morgan, M. E. (1998). Self-fertilization in brooding hermaphroditic Caribbean corals: evidence from molecular markers. Journal of Experimental Marine Biology and Ecology, 231(2), 225-238.

Budd, A. F., Fukami, H., Smith, N. D., \& Knowlton, N. (2012). Taxonomic classification of the reef coral family Mussidae (Cnidaria: Anthozoa: Scleractinia). Zoological Journal of the Linnean Society, 166(3), 465-529.

Coolidge, B. J., \& Howard, R. M. (1979). Animal histology procedures. US Department of Health, Education, and Welfare, Public Health Service, National Institutes of Health.

Duerden, J. E. (1902). West Indian Madreporarian polyps (Vol. 8). US Government Printing Office.

Darling, E. S., Alvarez-Filip, L., Oliver, T. A., McClanahan, T. R., \& Côté, I. M. (2012). Evaluating life-history strategies of reef corals from species traits. Ecology Letters, 15(12), 1378-1386.

Edmunds, P. J. (2005). Effect of elevated temperature on aerobic respiration of coral recruits. Marine Biology, 146(4), 655-663.

Fadlallah, Y. H. (1983). Sexual reproduction, development and larval biology in scleractinian corals. Coral Reefs, 2(3), 129-150.

Fukami, H., Budd, A. F., Paulay, G., Solé-Cava, A., Chen, C. A., Iwao, K., \& Knowlton, N. (2004). Conventional taxonomy obscures deep divergence between Pacific and Atlantic corals. Nature, 427(6977), 832-835.

Fukami, H., Chen, C. A., Budd, A. F., Collins, A., Wallace, C., Chuang, Y. Y., Chen, C., Dai, C.F., Iwao, K., Sheppard, C., \& Knowlton, N. (2008). Mitochondrial and nuclear genes suggest that stony corals are monophyletic but most families of stony corals are not (Order Scleractinia, Class Anthozoa, Phylum Cnidaria). PloS one, 3(9), e3222.

Hagman, D. K., Gittings, S. R., \& Deslarzes, K. J. P. (1998). Timing, species participation, and environmental factors influencing annual mass spawning at the Flower Garden Banks (Northwest Gulf of Mexico). Gulf of Mexico Science, 16, 170-179. 
357

358

359

360

361

362

363

364

365

366

367

368

369

370

371

372

373

374

375

376

377

378

379

380

381

382

383

384

385

386

387

388

389

390

391

392

393

394

395

396

397

398

399

400

401

402

403

404

405

Harrison, P. L. (1985). Sexual characteristics of scleractinian corals: systematic and evolutionary implications. In Proceedings of the 5th International Coral Reef Congress, 4, 337-342.

Harrison, P. L. (2011). Sexual reproduction of scleractinian corals. In Coral reefs: an ecosystem in transition 59-85. Springer Netherlands.

Harrison, P. L., \& Wallace, C. C. (1990). Reproduction, dispersal and recruitment of scleractinian corals. Ecosystems of the World, 25, 133-207.

Hoegh-Guldberg, O., Mumby, P. J., Hooten, A. J., Steneck, R. S., Greenfield, P., Gomez, E., Harvell, C.D., Sale, P.F., Edwards, A.J., Caldeira, K., \& Knowlton, N. (2007). Coral reefs under rapid climate change and ocean acidification. Science, 318(5857), 1737-1742.

Hughes, T. P. (1994). Catastrophes, phase shifts, and large-scale degradation of a Caribbean coral reef. Science-AAAS-Weekly Paper Edition,265(5178), 1547-1551.

Harvell, D., Aronson, R., Baron, N., Connell, J., Dobson, A., Ellner, S., Gerber, L., Kim, K., Kuris, A., McCallum, H., Lafferty, K., McKay, B., Porter, J., Pascual, M., Smith, G., Sutherland K., \& Ward, J. (2004). The rising tide of ocean diseases: unsolved problems and research priorities. Frontiers in Ecology and the Environment, 2(7), 375-382.

Irizarry-Soto, E., \& Weil, E. (2009). Spatial and temporal variability in juvenile coral densities, survivorship and recruitment in La Parguera, southwestern Puerto Rico. Caribbean Journal of Science, 45(2-3), 269-281.

Johnson, K. G. (1992). Synchronous planulation of Manicina areolata (Scleractinia) with lunar periodicity. Marine Ecology Progress Series, 87(3), 265-273.

Jokiel, P. L., Ito, R. Y., \& Liu, P. M. (1985). Night irradiance and synchronization of lunar release of planula larvae in the reef coral Pocillopora damicornis. Marine Biology, 88(2), 167174.

Knowlton, N., \& Jackson, J. B. (1993). Inbreeding and outbreeding in marine invertebrates. The natural history of inbreeding and outbreeding. University of Chicago Press, Chicago, 200-249.

Knowlton, N. (2001). The future of coral reefs. Proceedings of the National Academy of Sciences, 98(10), 5419-5425.

Lesser, M. P., Stochaj, W. R., Tapley, D. W., \& Shick, J. M. (1990). Bleaching in coral reef anthozoans: effects of irradiance, ultraviolet radiation, and temperature on the activities of protective enzymes against active oxygen. Coral Reefs, 8(4), 225-232.

Metz, J. A., Nisbet, R. M., \& Geritz, S. A. (1992). How should we define 'fitness' for general ecological scenarios? Trends in Ecology \& Evolution,7(6), 198-202.

Morales JA. (2006). Sexual reproduction in the Caribbean coral genus Mycetophyllia, in La Parguera Puerto Rico (Master's Thesis). Retrieved from ProQuest Dissertations and Theses. (Accession Order No. AAT 1438348)

Mumby, P. J. (1999). Bleaching and hurricane disturbances to populations of coral recruits in Belize. Marine Ecology Progress Series, 190, 27-35.

Neves, E., \& Pires, D. (2002). Sexual reproduction of Brazilian coral Mussismilia hispida (Verrill, 1902). Coral Reefs, 21(2), 161-168.

Padilla-Gamiño, J. L., Pochon, X., Bird, C., Concepcion, G. T., \& Gates, R. D. (2012). From parent to gamete: vertical transmission of Symbiodinium (Dinophyceae) ITS2 sequence assemblages in the reef building coral Montipora capitata. PLoS One, 7(6).

Petes, L. E., Harvell, C. D., Peters, E. C., Webb, M. A. H., \& Mullen, K. M. (2003). Pathogens compromise reproduction and induce melanization in Caribbean Sea fans. Marine Ecology Progress Series, 264, 167-171.

Pinzon J., \& Weil E. (2011). Cryptic species in the Atlantic-Caribbean scleractinian genus Meandrina: A multi-variable review of the taxonomy and description of the new species Meandrina jacksoni. Bulletin of Marine Science, 87(0), 823-853. 
406

407

408

409

410

411

412

413

414

415

416

417

418

419

420

421

422

423

424

425

426

427

428

429

430

431

432

433

434

435

436

437

438

439

440

441

442

443

444

445

446

447

448

449

450

451

452

453

454

Pires, D. O., Castro, C. B., \& Ratto, C. C. (1999). Reef coral reproduction in the Abrolhos Reef Complex, Brazil: the endemic genus Mussismilia. Marine Biology, 135(3), 463-471.

Pires, D. O., Castro, C. B., \& Ratto, C. C. (2002). Reproduction of the solitary coral Scolymia wellsi Laborel (Cnidaria, Scleractinia) from the Abrolhos reef complex, Brazil. In Proceedings of the 9th International Coral Reef Congress, 9(1), 381-384.

R Core Team. 2015. R: A language and environment for statistical computing. R Foundation for Statistical Computing, Vienna, Austria. URL https://www.R-project.org/.

RStudio Team. 2015. RStudio: Integrated Development for R. RStudio, Inc., Boston, MA URL http://www.rstudio.com/.

Richmond, R. H., \& Hunter, C. L. (1990). Reproduction and recruitment of corals: comparisons among the Caribbean, the Tropical Pacific, and the Red Sea. Marine Ecology Progress Series. 60(1), 185-203.

Ruiz-Moreno, D., Willis, B. L., Page, A. C., Weil, E., Cróquer, A., Vargas-Angel, B., JordanGarza, A.G., Jordán-Dahlgren, E., \& Harvell, C. D. (2012). Global coral disease prevalence associated with sea temperature anomalies and local factors. Diseases of Aquatic Organisms, 100, 249-261.

Sawada, H., Morita, M., \& Iwano, M. (2014). Self/non-self recognition mechanisms in sexual reproduction: new insight into the self-incompatibility system shared by flowering plants and hermaphroditic animals. Biochemical and biophysical research communications, 450(3), 1142-1148.

Sherman, C. D. H. (2008). Mating system variation in the hermaphroditic brooding coral, Seriatopora hystrix. Heredity, 100(3), 296-303.

Soong, K. (1993). Colony size as a species character in massive reef corals. Coral Reefs, 12(2), 77-83.

Soong, K. (1991). Sexual reproductive patterns of shallow-water reef corals in Panama. Bulletin of Marine Science, 49(3), 832-846.

Steiner, S. C. (1993). Comparative ultrastructural studies on scleractinian spermatozoa (Cnidaria, Anthozoa). Zoomorphology, 113(2), 129-136.

Steiner, S. C. (1995). Spawning in scleractinian corals from SW Puerto Rico (West Indies). Bulletin of Marine Science, 56(3), 899-902.

Szmant, A., \& Gassman, N. J. (1990). The effects of prolonged "bleaching" on the tissue biomass and reproduction of the reef coral Montastrea annularis. Coral Reefs, 8(4), 217-224.

Szmant-Froelich, A. (1984). Reef coral reproduction: diversity and community patterns. In Advances in Reef Science, Joint Meeting International Society for Reef Studies and Atlantic Reef Committee University of Miami.

Szmant-Froelich, A. (1985). The effect of colony size on the reproductive ability of the Caribbean coral Montastrea annularis (Ellis and Solander). In Proceedings of the 5th International Coral Reef Congress, 295-300.

Szmant, A. M. (1986). Reproductive ecology of Caribbean reef corals. Coral Reefs, 5(1), 43-53.

Tchernov, D., Gorbunov, M. Y., de Vargas, C., Yadav, S. N., Milligan, A. J., Häggblom, M., \& Falkowski, P. G. (2004). Membrane lipids of symbiotic algae are diagnostic of sensitivity to thermal bleaching in corals. Proceedings of the National Academy of Sciences of the United States of America, 101(37), 13531-13535.

Van Moorsel, G. W. N. M. (1983). Reproductive strategies in two closely related stony corals (Agaricia, Scleractinia). Marine Ecology Progress Series, 13, 273-283.

Van Woesik, R., Lacharmoise, F., \& Köksal, S. (2006). Annual cycles of solar insolation predict spawning times of Caribbean corals. Ecology letters, 9(4), 390-398.

Van Woesik, R. (2009). Calm before the spawn: global coral spawning patterns are explained by regional wind fields. Proceedings of the Royal Society of London B: Biological Sciences. 
455

456

457

458

459

460

461

462

463

464

465

466

467

468

469

470

471

472

473

474

475

476

477

478

479

480

481

482

483

484

485

486

487

488

489

490

491

492

493
Vermeij, M. J. A. (2006). Early life-history dynamics of Caribbean coral species on artificial substratum: the importance of competition, growth and variation in life-history strategy. Coral Reefs, 25(1), 59-71.

Vermeij, M. J. A., Sampayo, E., Bröker, K., \& Bak, R. P. M. (2004). The reproductive biology of closely related coral species: gametogenesis in Madracis from the southern Caribbean. Coral Reefs, 23(2), 206-214.

Weil, E. (2002). Coral disease epizootiology: status and research needs. Coral health and disease: developing a national research plan. Coral Health and Disease Consortium, Charleston South Carolina.

Weil, E. (2003). The corals and coral reefs of Venezuela. Latin American Coral Reefs. Amsterdam: Elsevier Science, 303-330.

Weil, E. (2004). Coral reef diseases in the wider Caribbean. In Coral Health and Disease, 35-68. Springer Berlin Heidelberg.

Weil, E., Cróquer, A., \& Urreiztieta, I. (2009a). Yellow band disease compromises the reproductive output of the Caribbean reef-building coral Montastraea faveolata (Anthozoa, Scleractinia). Diseases of Aquatic Organisms, 87(1-2), 45-55.

Weil, E., Croquer, A., \& Urreiztieta, I. (2009b). Temporal variability and impact of coral diseases and bleaching in La Parguera, Puerto Rico from 2003-2007. Caribbean Journal of Science, 45(2-3), 221-246.

Weil, E., Smith, G., \& Gil-Agudelo, D. L. (2006). Status and progress in coral reef disease research. Diseases of Aquatic Organisms, 69(1), 1-7.

Weil, E., Urreiztieta, I., \& Garzón-Ferreira, J. (2002). Geographic variability in the incidence of coral and octocoral diseases in the wider Caribbean. In Proceedings of the 9th International Coral Reef Symposium, 2, 1231-1237.

Weil, E., \& Vargas, W. L. (2010). Comparative aspects of sexual reproduction in the Caribbean coral genus Diploria (Scleractinia: Faviidae). Marine Biology,157(2), 413-426.

Weil, E., \& Rogers, C. S. (2011). Coral reef diseases in the Atlantic-Caribbean. In Coral reefs: An Ecosystem in Transition 465-491. Springer Netherlands.

Willis, B. L., Babcock, R. C., Harrison, P. L., Oliver, J. K., \& Wallace, C. C. (1985). Patterns in the mass spawning of corals on the Great Barrier Reef from 1981 to 1984. In: Proceedings of the 5th International Coral Reef Congress, 343-348.

Wilson, J. R., \& Harrison, P. L. (1997). Sexual reproduction in high latitude coral communities at the Solitary Islands, eastern Australia. In Proceedings of the 8th International Coral Reef Congress, 533-538.

Wyers, S. C., Barnes, H. S., \& Smith, S. R. (1991). Spawning of hermatypic corals in Bermuda: a pilot study. Hydrobiologia, 216(1), 109-116.

Yakovleva, I. M., Baird, A. H., Yamamoto, H. H., Bhagooli, R., Nonaka, M., \& Hidaka, M. (2009). Algal symbionts increase oxidative damage and death in coral larvae at high temperatures. Marine Ecology Progress Series, 378, 105-112. 


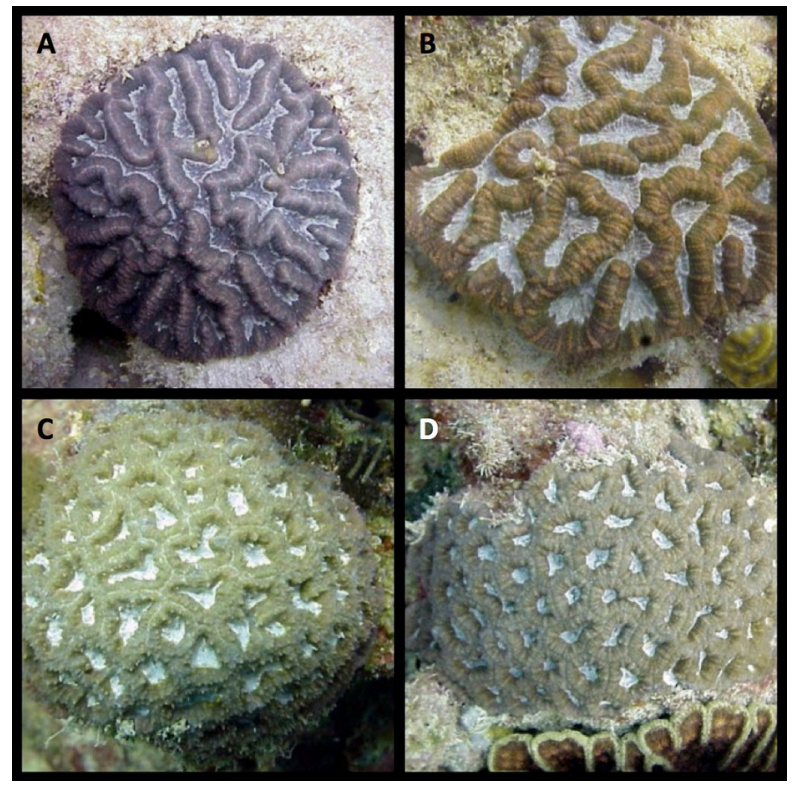

Fig. 1 (A \& B) Isophyllia rigida and (C \& D) Isophyllia sinuosa. Photo credit: Ernesto Weil.

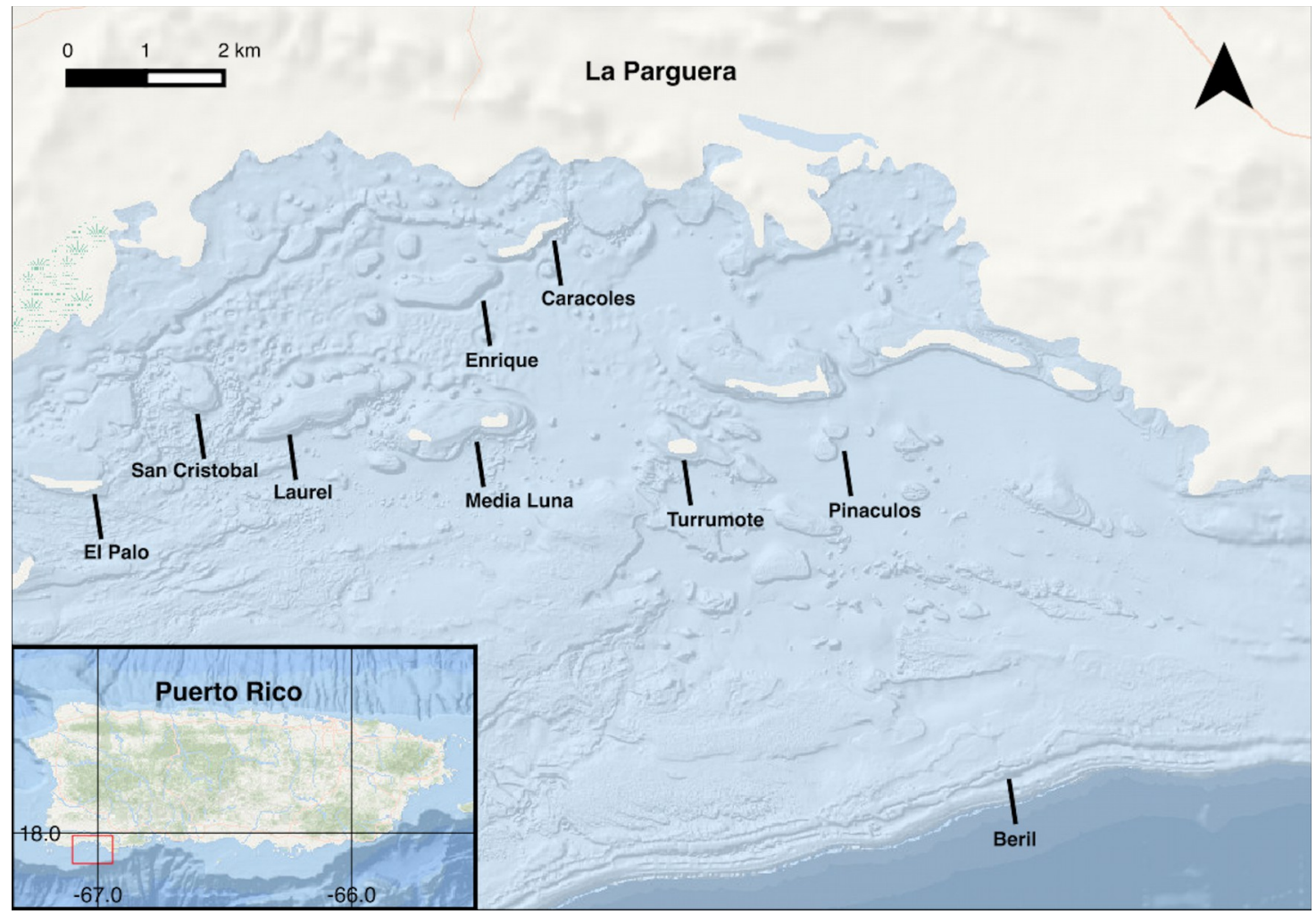

Fig. 2 Map of La Parguera, Puerto Rico with study sites. Image made with QGIS using NOAA’s National Centers for Enviromental Information (NCEI) Multibeam Bathymetric Surveys Dataset. 

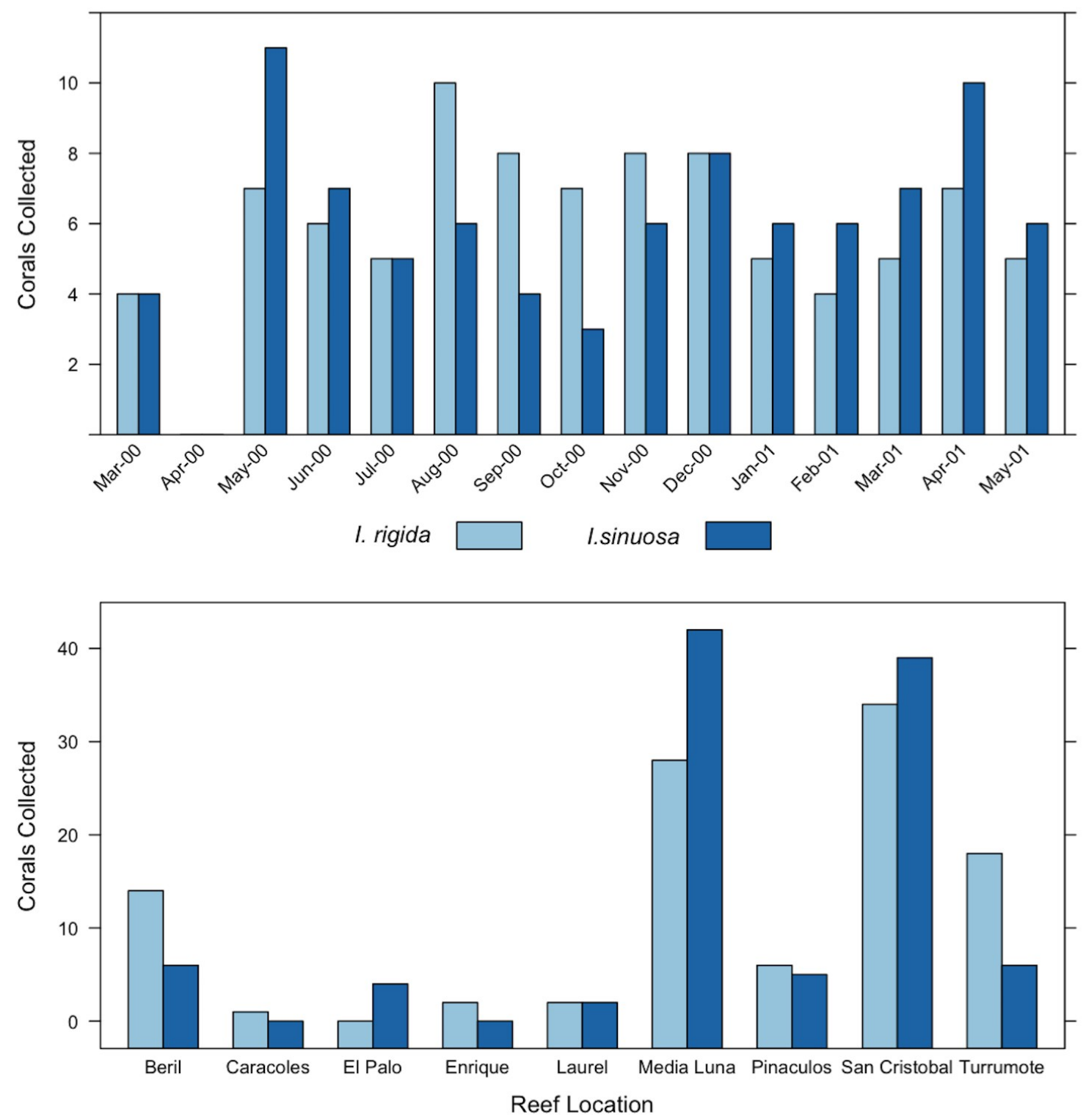

Fig. 3 (A) Number of samples collected per month (B) Number of samples collected per location. 


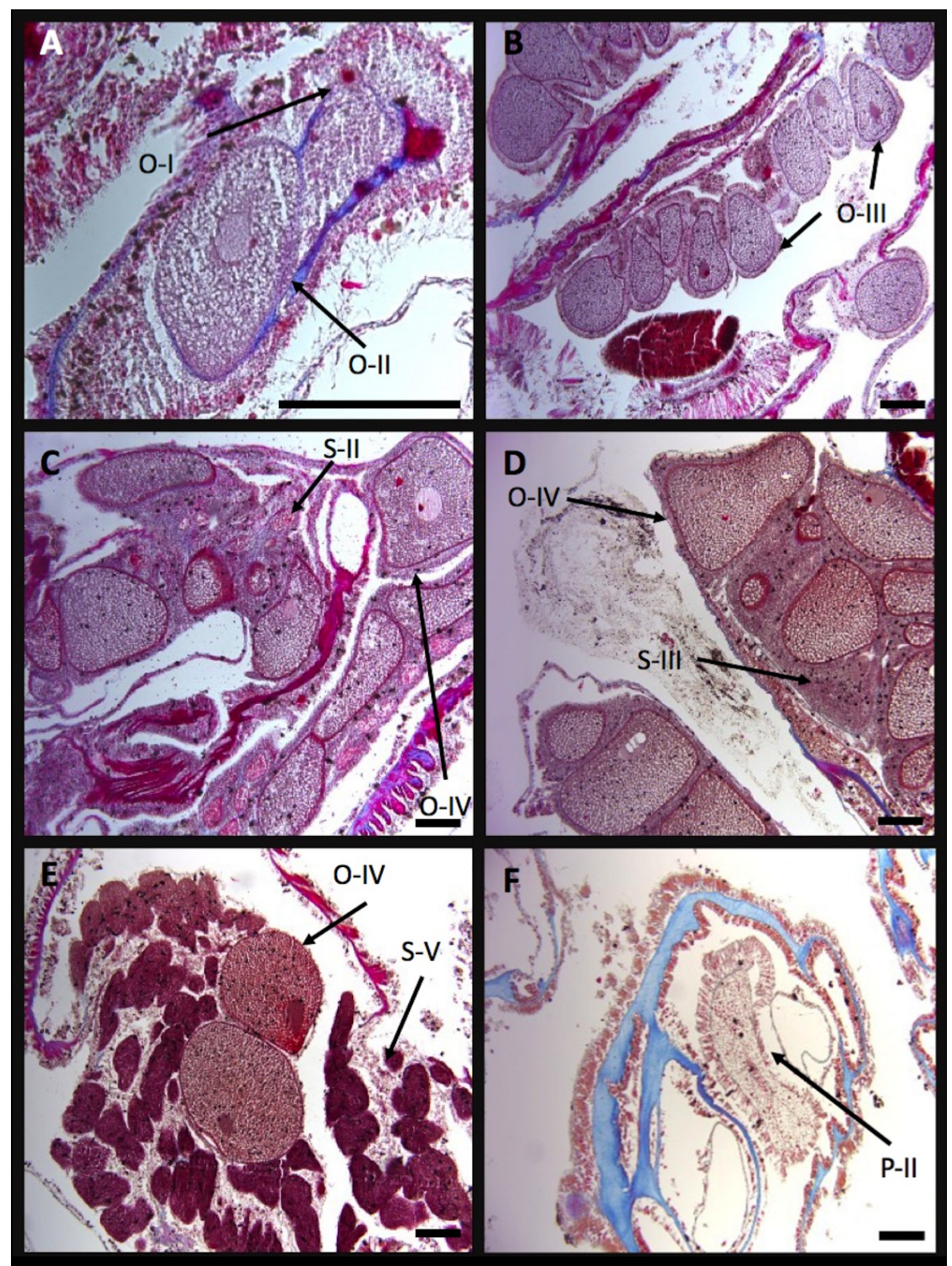

Fig. 4 Developmental stages of oocytes (O) and spemaries (S) in I. sinuosa. (A) stage I and II oocytes, (B) stage III oocytes, (C) stage II spermaries and stage IV oocytes, (D) stage IV oocytes and stage III spermaries, (E) stage IV oocytes and stage V spermaries, and (F) stage II planula. Scale bar measures $100 \mu \mathrm{m}^{2}$. 

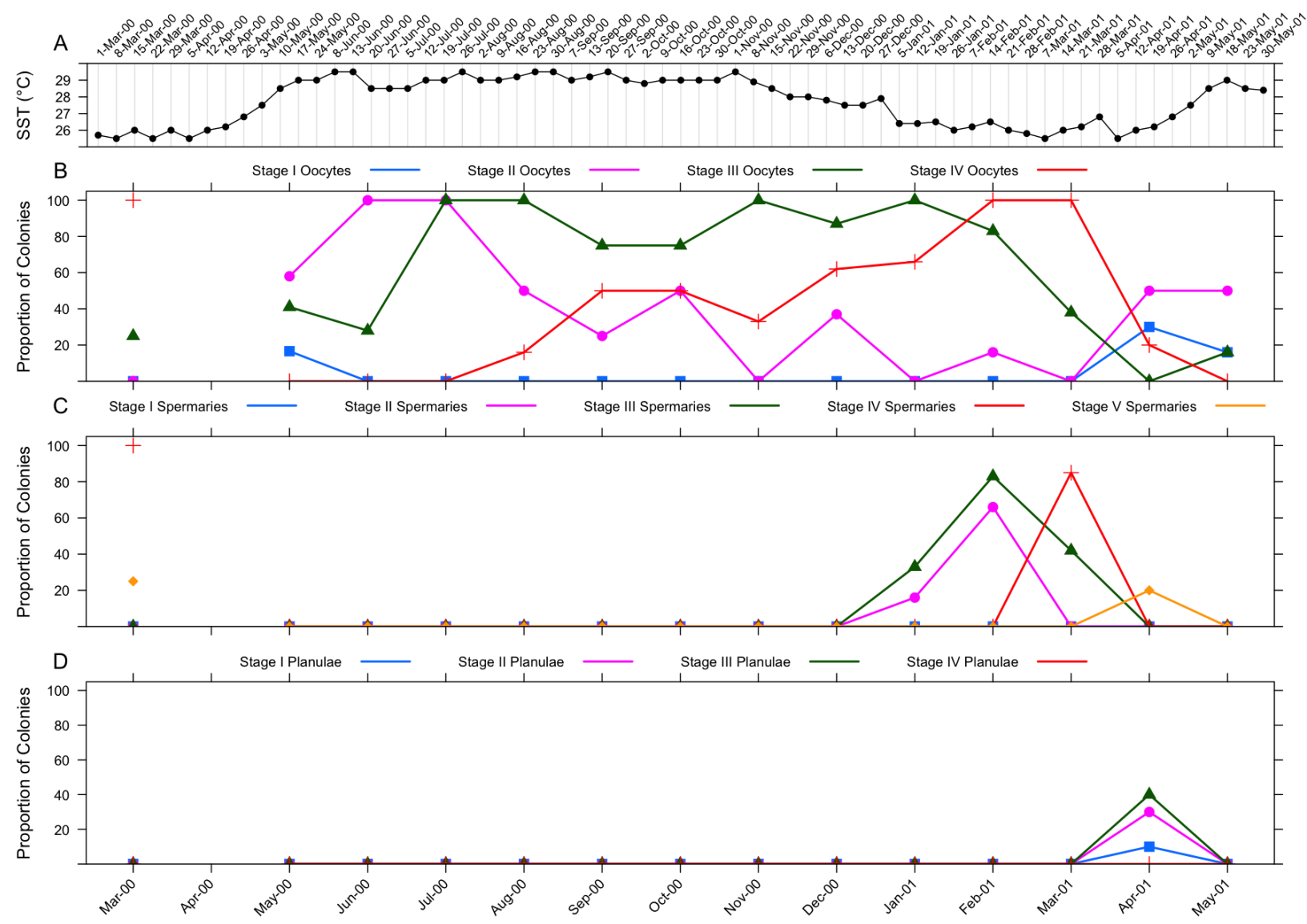

Fig. 5 (A) Sea surface temperature ranges in La Parguera, Puerto Rico. Adjusted values of relative proportions of colonies of $I$. sinuosa in each gametogenetic stage of (B) oogenesis, (C) spermatogenesis, and (D) embryogenesis from March 2000 to May 2001. 


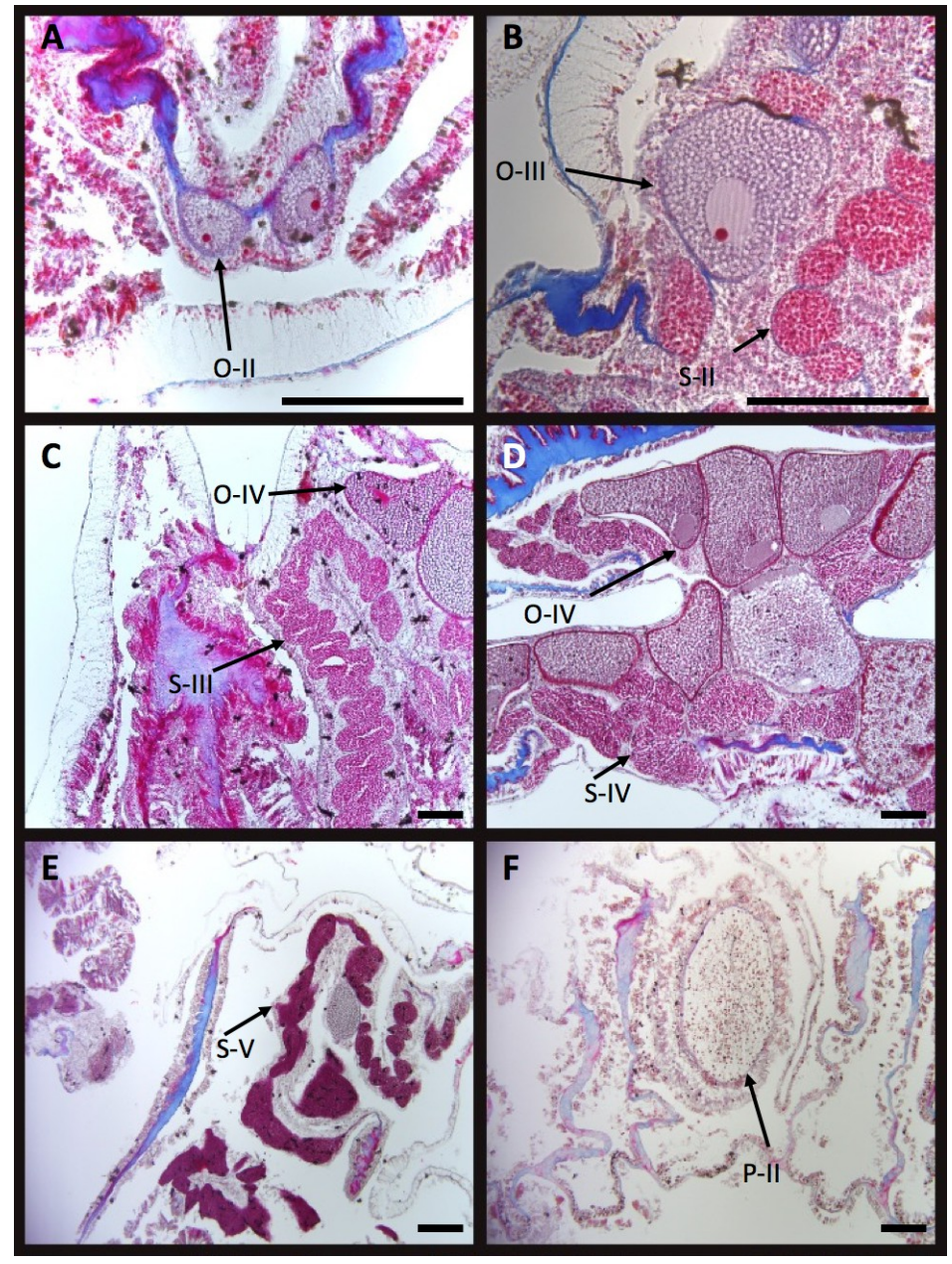

Fig. 6 Developmental stages of oocytes (O) and spemaries (S) in I. rigida. (A) Stage II oocytes in the mesoglea, (B) Stage III oocytes and spermaries, (C) stage III spermaries and stage IV oocytes, (D) stage IV oocytes and spermaries, (E) stage V spermaries, and (F) stage II planula. Scale bar measures $100 \mu \mathrm{m}^{2}$. 

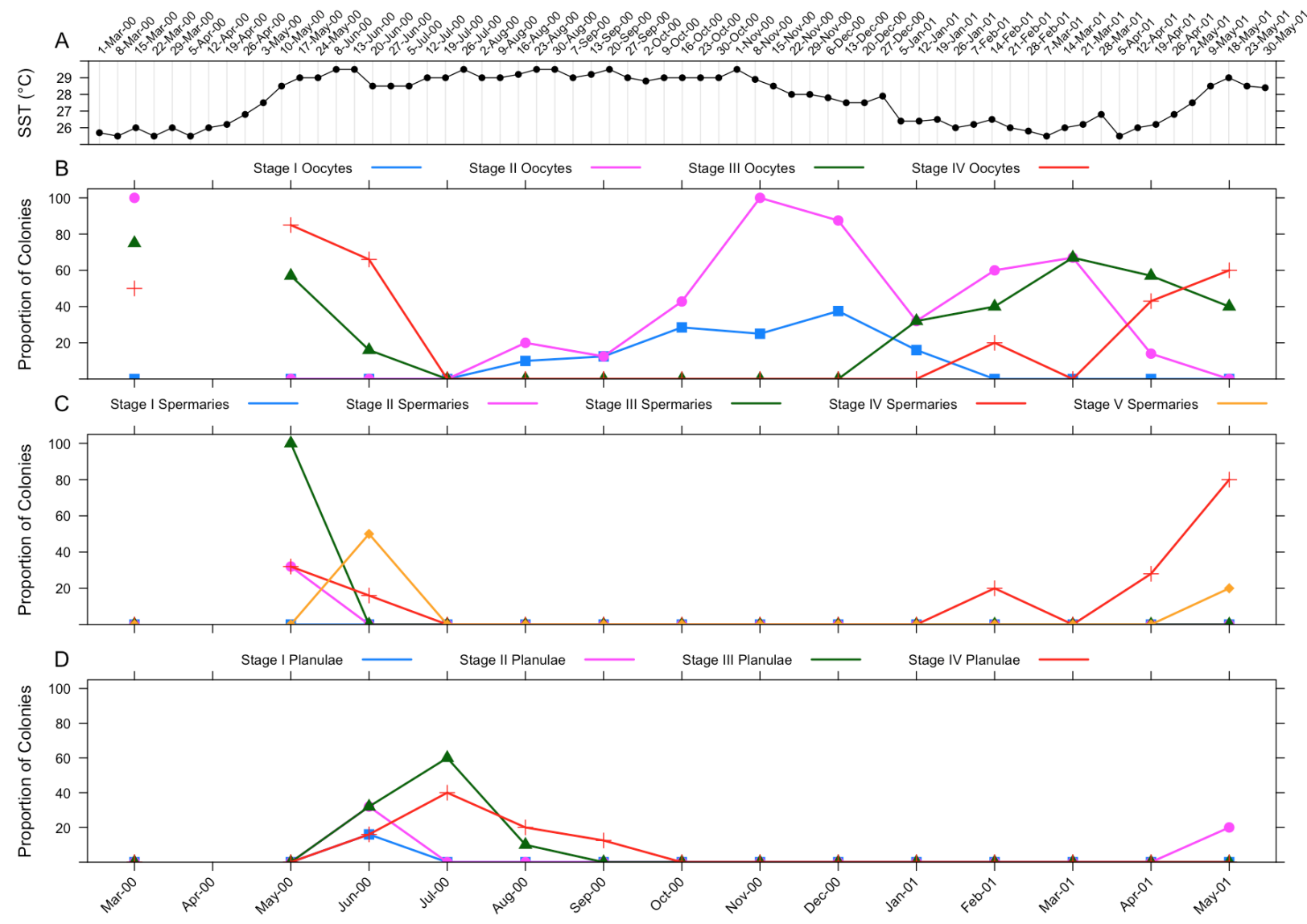

Fig. 7 (A) Sea surface temperature ranges in La Parguera, Puerto Rico. Adjusted values of relative proportions of colonies of I. rigida in each gametogenetic stage of (B) oogenesis, (C) spermatogenesis, and (D) embryogenesis from March 2000 to May 2001. 
A

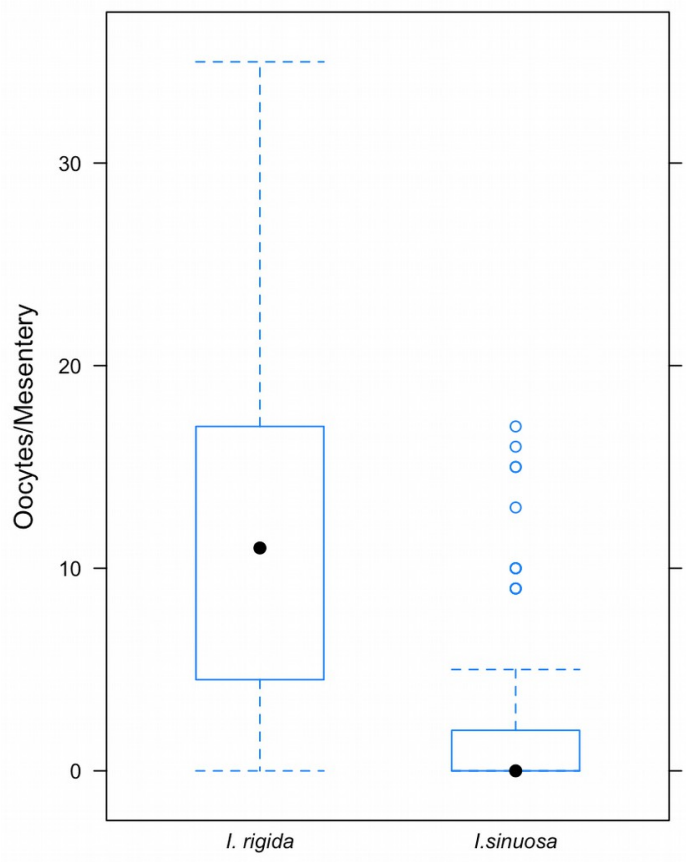

B

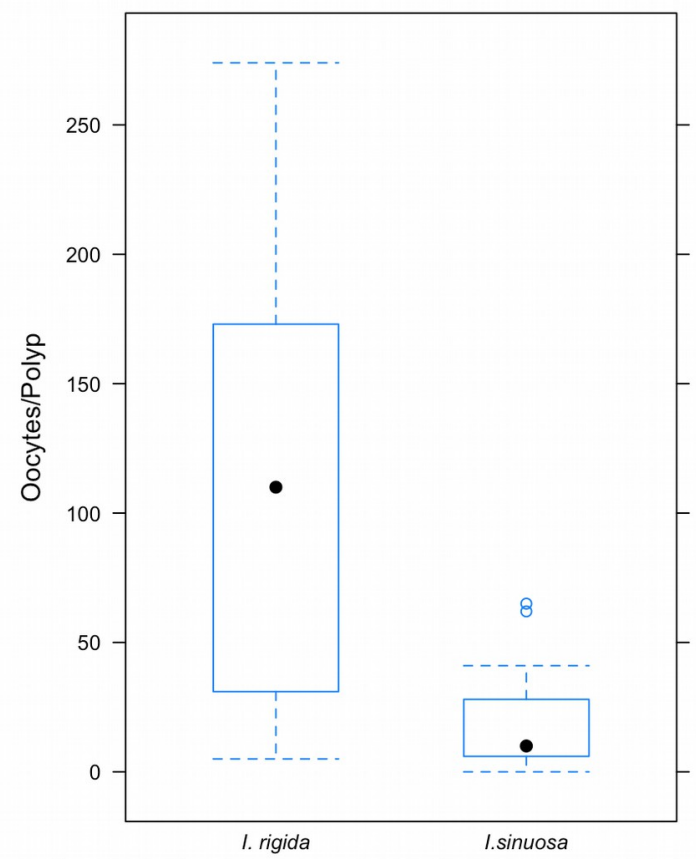

Fig. 8 (A) Average mesenterial (eggs/mesentery) fecundity and (B) polyp (eggs/polyp) fecundity in $I$. sinuosa and I. rigida. Whiskers represent standard error.
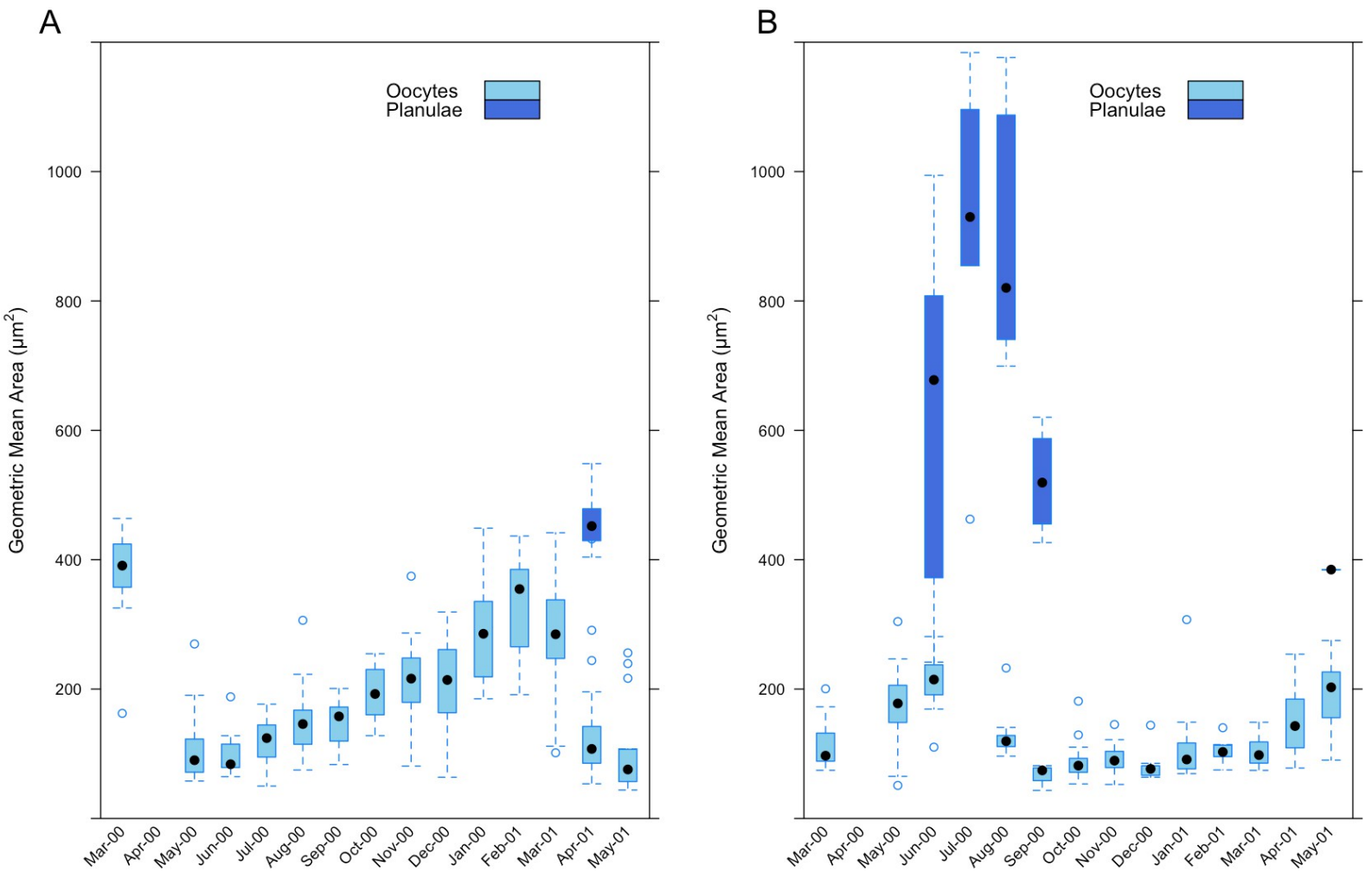

Fig. 9 Monthly geometric mean oocyte and planulae areas in (A) I. sinuosa and (B) I. rigida. 
Table 1 Comparison of reproductive characteristics of Mussidae (Clade XXI)

\begin{tabular}{|c|c|c|c|c|c|}
\hline Subfamily & Genus & Species & $\begin{array}{l}\text { Sexual } \\
\text { Pattern }\end{array}$ & $\begin{array}{l}\text { Mode of } \\
\text { Development }\end{array}$ & Source \\
\hline \multirow[t]{11}{*}{ Mussinae } & Mussa & M. angulosa & $\mathrm{H}$ & & Steiner 1993 \\
\hline & Isophyllia & I. rigida & $\mathbf{H}$ & Brooding & This study \\
\hline & & I. sinuosa & $\mathbf{H}$ & Brooding & Duerden 1902; This study \\
\hline & Mycetophyllia & M. ferox & $\mathrm{H}$ & Brooding & $\begin{array}{l}\text { Szmant 1984; Szmant 1986; Morales } \\
2006\end{array}$ \\
\hline & & M. aliciae & $\mathrm{H}$ & Brooding & Morales 2006 \\
\hline & & M. lamarckiana & $\mathrm{H}$ & Brooding & Morales 2006 \\
\hline & & M. danaana & $\mathrm{H}$ & Brooding & Morales 2006 \\
\hline & & M. reesi & & & \\
\hline & $\begin{array}{l}\text { Scolymia } \\
\text { (Atlantic) }\end{array}$ & S. cubensis & $\mathrm{H}$ & Brooding & Weil unpublished data \\
\hline & & S. lacera & $\mathrm{H}$ & Brooding & Weil unpublished data \\
\hline & & S. wellsi & $\mathrm{H}$ & Brooding & Pires et al. 2002 \\
\hline \multirow[t]{10}{*}{ Faviinae } & $\begin{array}{l}\text { Favia } \\
\text { (Atlantic) }\end{array}$ & F. fragrum & $\mathrm{H}$ & Broadcast & $\begin{array}{l}\text { Duerden 1902; Fadlallah 1983; Szmant } \\
\text { 1986; Richmond and Hunter 1990; } \\
\text { Soong } 1991\end{array}$ \\
\hline & Colpophyllia & C. amaranthus & $\mathrm{H}$ & Broadcast & Weil unpublished data \\
\hline & & C. natans & $\mathrm{H}$ & Broadcast & $\begin{array}{l}\text { Steiner 1995; Hagman et al. 1998; } \\
\text { Boland 1998; Weil unpublished data }\end{array}$ \\
\hline & Diploria & D.labyrinthiformis & $\mathrm{H}$ & Broadcast & $\begin{array}{l}\text { Duerden 1902; Fadlallah 1983; Wyers et } \\
\text { al. 1991; Weil and Vargas } 2009\end{array}$ \\
\hline & Pseudodiploria & D. clivosa & $\mathrm{H}$ & Broadcast & Soong et al. 1991;Weil and Vargas 2009 \\
\hline & & D. strigosa & $\mathrm{H}$ & Broadcast & $\begin{array}{l}\text { Szmant 1986; Richmond and Hunter } \\
\text { 1990; Soong 1991; Steiner 1995; Weil } \\
\text { and Vargas } 2009\end{array}$ \\
\hline & Manicina & M. areolata & $\mathrm{H}$ & Brooding & $\begin{array}{l}\text { Duerden 1902; Fadlallah 1983; } \\
\text { Richmond and Hunter 1990; Johnson } \\
1992\end{array}$ \\
\hline & Mussismilia & M.hispida & $\mathrm{H}$ & Broadcast & Neves and Pires 2002; Pires, et al. 1999 \\
\hline & & M. hartii & $\mathrm{H}$ & Broadcast & Pires et al. 1999 \\
\hline & & M. brazilensis & $\mathrm{H}$ & Broadcast & Pires et al. 1999 \\
\hline
\end{tabular}

